Jurnal Laut Khatulistiwa, Vol. 4 No. 3 (October, 2021), Hal. 92-100.

ISSN : 2614-6142 (Printed), 2614-8005 (Online)

http://jurnal.untan.ac.id/index.php/lk

JURNAL LAUT

KHATULISTIWA

\title{
Studi Karakteristik Arus Pasang Surut Muara Sungai Mempawah
}

\section{The Characteristics of Tidal Current In Mempawah River Estuary}

\author{
Topang Gunawan ${ }^{*}$, Arie Antasari Kushadiwijayanto², Yusuf Arief Nurrahman², Muliadi², \\ Risko $^{2}$ \\ ${ }^{1}$ Program Studi Ilmu Kelautan Ilmu Kelautan, FMIPA Universitas Tanjungpura, Pontianak, Indonesia \\ ${ }^{2}$ Laboratorium Ilmu Kelautan Ilmu Kelautan, FMIPA Universitas Tanjungpura, Pontianak, Indonesia \\ ${ }^{*}$ E-mail : topanggunawan@student.untan.ac.id
}

Received : 28 Mei 2021; Accepted: 23 September 2021

Published: 31 October (C) Author(s) 2021. This article is open access

\begin{abstract}
Research on the effect of tides in current movement patterns at the Mempawah River Estuary has been carried out from February to March 2019. The purpose of this research is to find out the current characteristics generated by the tidal phenomenon or better known as tidal currents. The result of this study is showed the tide at the location experiencing distortion due to the effect of depth reduced, so that resulting in the appearance of tidal asymmetry. Based on the results of the visualization the data measurements noted that the current dominant moves outward towards the sea, the movement of the current entering the river was found only at spring tide during the new moon phase and full moon phase. The current pattern characteristics obtained show the current moves into the river when the water starts to rise with a relatively small current speed. Otherwise when the water starts to fall the current speed has increased significantly and change in the direction of movement outward towards to the sea.
\end{abstract}

Keywords : Tides, Tidal Currents, Tidal Asymmetry, Mempawah River Estuary

\begin{abstract}
Abstrak
Penelitian mengenai pengaruh pasang surut terhadap perubahan pola pergerakan arus di Muara Sungai Mempawah telah dilaksanakan pada bulan Februari sampai dengan Maret 2019. Tujuan penelitian ini adalah untuk mengetahui karakteristik arus yang dibangkitkan oleh fenomena pasang surut atau lebih dikenal sebagai arus pasut. Hasil dari penelitian ini menunjukan bahwa pasang surut di lokasi penelitian mengalami distorsi akibat pengaruh berkurangnya kedalaman sehingga menimbulkan munculnya fenomena asimteri pasut. Berdasarkan hasil visualisasi data pengamatan diketahui bahwa arus lebih dominan bergerak keluar menuju laut, pergerakan arus yang masuk menuju sungai hanya ditemukan pada pasang purnama saat fase bulan baru dan bulan purnama. Karakteristik pola arus yang didapatkan menunjukan arus akan bergerak memasuki sungai ketika air mulai pasang dengan kecepatan arus yang relatif kecil, sebaliknya ketika air mulai surut kecepatan arus mengalami peningkatan yang signifikan ditandai dengan perubahan arah pergerakan arus yang keluar menuju laut.
\end{abstract}

Kata kunci : Pasang Surut, Arus Pasang Surut, Asimetri Pasut, Muara Sungai Mempawah

\section{Pendahuluan}

Muara Sungai Mempawah merupakan wilayah pesisir yang berada di Kecamatan Mempawah Hilir, Kabupaten Mempawah, Provinsi Kalimantan Barat (BPS, 2018). Muara sungai merupakan kawasan yang menjadi tempat bertemunya dua massa air, yaitu air asin yang berasal dari laut dan air tawar yang berasal dari sungai. Setiap waktu, lautan mengalami perubahan kondisi pasang dan surut secara periodik yang dapat mempengaruhi pola pergerakan arus. Arus yang terjadi akibat perubahan tinggi permukaan air laut disebut sebagai arus pasut (Sudarto, 1993).

Kajian terhadap pola pergerakan arus yang dihubungkan dengan proses pasang surut merupakan hal yang sangat penting dilakukan, 
Jurnal Laut Khatulistiwa, Vol. 4. No. 3 (October, 2021), Hal. 92-100.

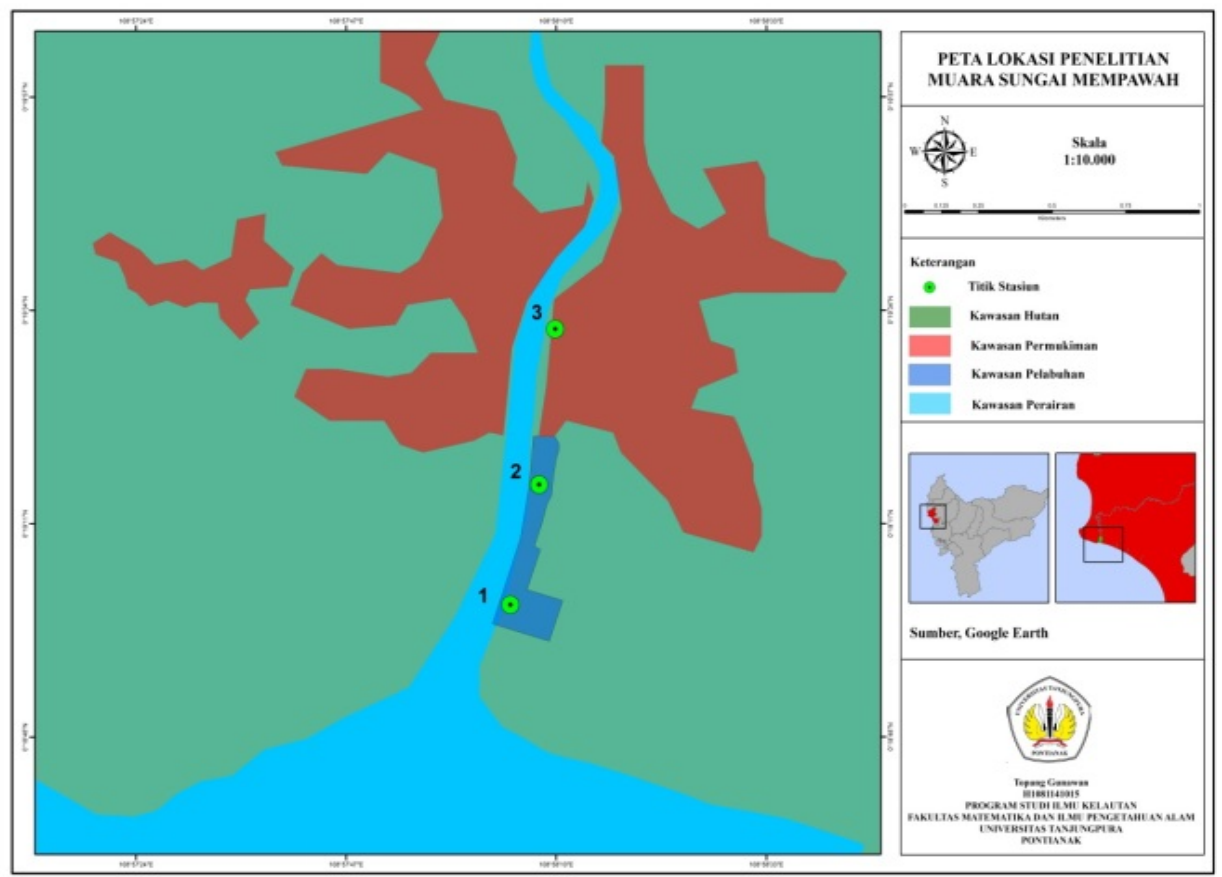

Gambar 1. Peta Lokasi Penelitian, stasiun pengamatan ditandai dengan titik warna hijau

khususnya pada perairan teluk atau muara sungai karena merupakan gaya penggerak utama sirkulasi massa airnya (Triadmojo, 1999). Pada saat muka air laut lebih tinggi daripada sungai (pasang), arus pasut akan bergerak memasuki sungai. Sementara pada saat muka air laut lebih rendah daripada sungai (surut), arus pasut akan bergerak keluar menuju laut (Kisnarti dan Prasita, 2019).

Informasi tentang arus pasut sangat berguna dalam upaya mengatasi masalah peningkatan sedimentasi yang terjadi di Muara Sungai Mempawah. Efek arus pasut dapat membawa massa air bersalinitas tinggi yang berasal dari laut masuk ke dalam sungai atau estuari (Widyastuti, 2014). Masuknya massa air bersalinitas tinggi tersebut menyebabkan konsentrasi sedimen melayang meningkat seperti di Changjiang Estuari, terutama pada saat kondisi slack water (Niroomandi et al, 2017). Namun proses transport sedimen melayang sangat kompleks, karena sifat sedimen yang kohesif dapat mengalami consolidation atau flocculation (Dronkers, 1986). Sehingga penelitian ini akan difokuskan pada keadaan arus pasut di lapangan.

Tujuan dari penelitian ini adalah mengetahui pengaruh pasang surut terhadap pola perubahan arah dan kecepatan arus, serta mengamati munculnya fenomena asimetri pasut (tidal asymmetry).

Manfaat dari penelitian ini adalah tersedianya data dan informasi mengenai kerakteristik arus yang dibangkitkan oleh pasang surut.

\section{Metodologi Penelitian}

\subsection{Waktu dan Tempat Penelitian}

Pengambilan data elevasi muka air (vertikal) dan arus (horizontal) dilakukan selama 29 hari dengan interval pengukuran setiap satu jam, dimulai dari tanggal 04 Februari s.d 04 Maret 2019 di Kuala Mempawah, Kecamatan Mempawah Hilir, Kabupaten Mempawah, Provinsi Kalimantan Barat.

\subsection{Penentuan Stasiun Pengamatan}

Metode yang digunakan dalam penentuan stasiun pengamatan dilakukan berdasarkan pertimbangan tertentu dengan menggunakan metode Purposive Sampling. Jarak dari masingmasing stasiun pengamatan adalah sekitar 500 $\mathrm{m}$, sehingga jarak total dari Stasiun 1 sampai Stasiun 3 adalah $\pm 1 \mathrm{~km}$. Hal ini bertujuan untuk mendapatkan pola pergerakan arus pasang surut yang bersifat bolak balik di muara sungai. 


\subsection{Pengambilan Data Pasang Surut $\quad V=\frac{s}{t}$}

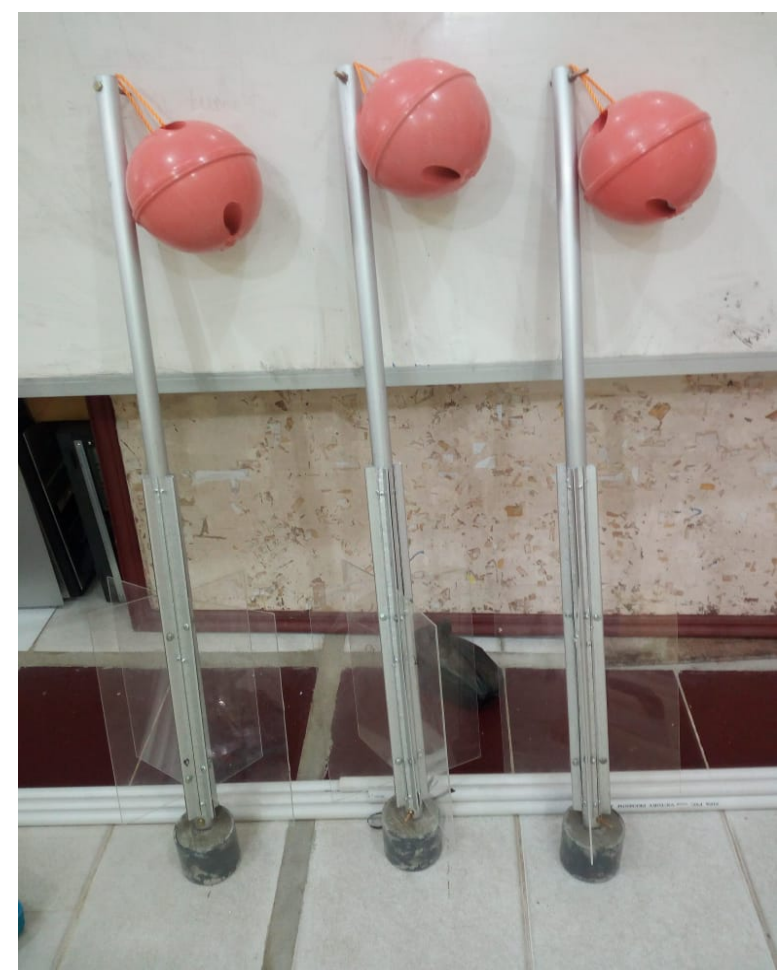

Gambar 2. Current Drouge Jenis Sensor Silang

Pengamatan pasang surut dilakukan untuk mendapatkan data perubahan tinggi muka air pada suatu perairan yang diamati. Rentang waktu pengamatan pasang surut yang digunakan pada penelitian ini adalah 29 piantan (1 piantan sama dengan 24 jam) dengan interval pengukuran setiap satu jam. Pengukuran data pasang surut dilakukan dengan cara melihat ketinggian muka air menggunakan bantuan palm pasut.

\subsection{Pengambilan Data Kecepatan dan Arah Arus}

Pengukuran data kecepatan dan arah arus dilakukan menggunakan metode Eulerian. Menurut Pickard, (1975) pengukuran arus dalam sistem eulerian dilakukan pada satu titik yang tetap terhadap fluida. Alat yang digunakan untuk mengukur kecepatan dan arah arus menggunakan current drouge jenis sensor silang yang dikembangkan oleh Sudarto, (1993). Alat ini merupakan alat ukur sederhana, namun hasilnya dapat dipertanggung jawabkan secara ilmiah. Contoh alat ukur yang digunakan pada penelitian ini dapat dilihat pada Gambar 2.

Hasil pengukuran data kecepatan arus kemudian dihitung menggunakan persamaan :
Dimana :

$\mathrm{V}=$ Kecepatan arus (m/det)

$\mathrm{s}=$ Panjang lintasan current drouge (m)

$\mathrm{t}=$ Waktu tempuh current drouge (detik)

\section{Hasil dan Pembahasan}

\subsection{Pasang Surut}

Berdasarkan hasil visualisasi data pengamatan pasang surut yang diplot ke dalam bentuk grafik menunjukan bahwa terjadi dua kali periode pasang purnama dan pasang perbani. Menurut Ongkosongo, (1989) dalam Fadilah et al., (2014) menyatakan bahwa pembentukan pasang surut air laut sangat dipengaruhi oleh revolusi bulan terhadap bumi, dimana periode untuk menyelesaikan revolusi tersebut selama 29,5 hari.

Meskipun ukuran bulan lebih kecil daripada matahari, gaya gravitasi bulan dua kali lebih besar daripada gaya gravitasi matahari karena jarak bulan lebih dekat daripada jarak matahari ke bumi. Sehingga fenomena pasang surut di bumi lebih dominan dipengaruhi oleh gaya gravitasi bulan (Mahatmawati dan Hidayah, 2010; Nugroho et al, 2015).

Akibat pengaruh kombinasi posisi bumi, bulan dan matahari menimbulkan perbedaan 
Jurnal Laut Khatulistiwa, Vol. 4. No. 3 (October, 2021), Hal. 92-100.
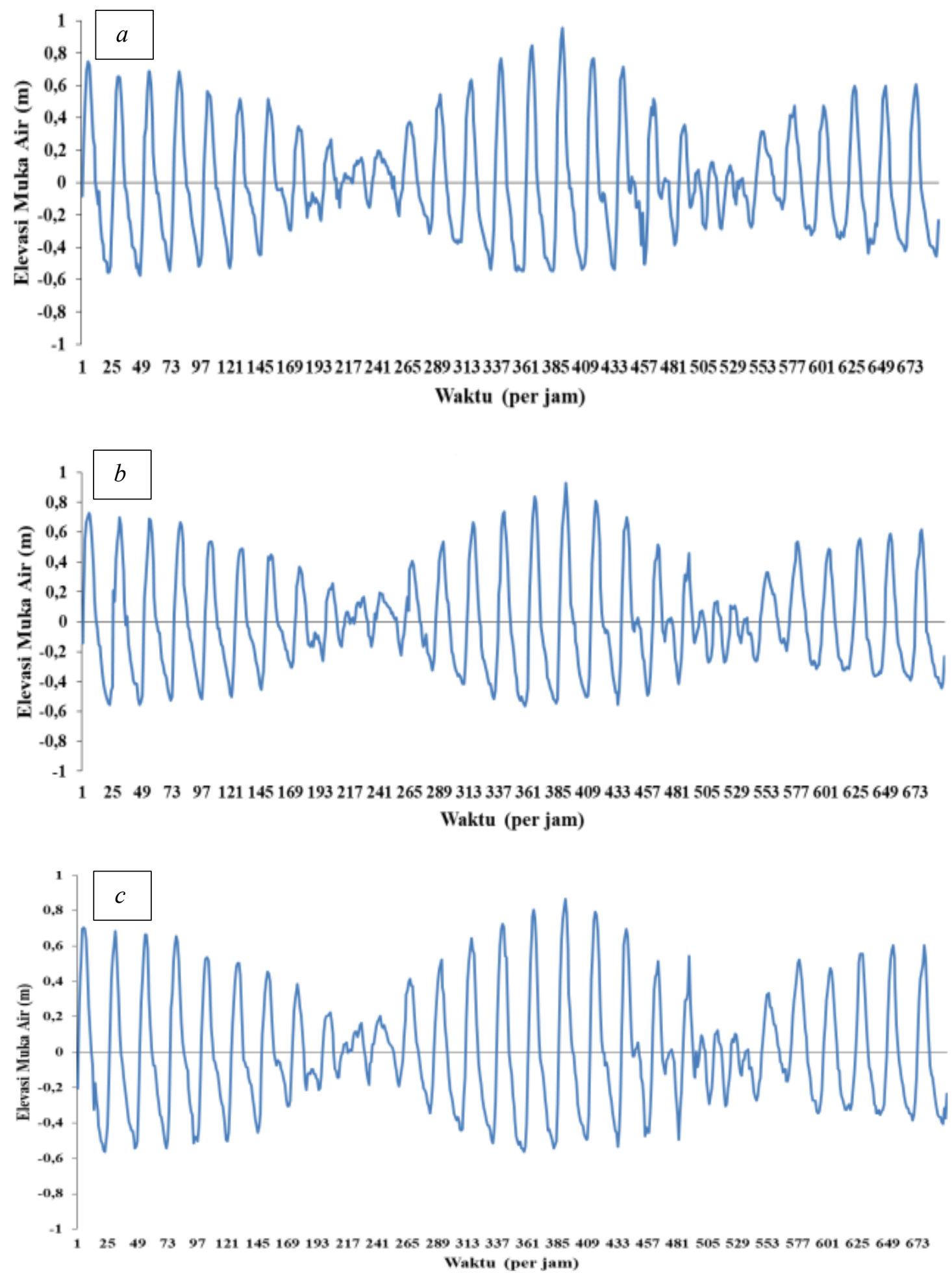

Gambar 3. Grafik pola pasang surut di Muara Mempawah: $a$ ) Stasiun 1; $b$ ) Stasiun 2; c) Stasiun 3

nilai rentang pasut yang cukup signifikan antara periode pasang purnama dan pasang perbani. Nilai rentang pasut yang didapatkan pada periode pasang purnama, saat fase bulan baru secara berurutan dari Stasiun 1, 2 dan 3 sebesar $126 \mathrm{~cm}, 122 \mathrm{~cm}$ dan $120 \mathrm{~cm}$.
Sementara saat fase bulan purnama sebesar $150 \mathrm{~cm}, 147 \mathrm{~cm}$ dan $139 \mathrm{~cm}$. Sedangkan pada periode pasang perbani, saat fase seperempat awal bulan nilai rentang pasut yang didapatkan sebesar $50 \mathrm{~cm}, 52 \mathrm{~cm}$ dan $43 \mathrm{~cm}$. Selanjutnya saat fase seperempat akhir bulan 
Jurnal Laut Khatulistiwa, Vol. 4. No. 3 (October, 2021), Hal. 92-100.
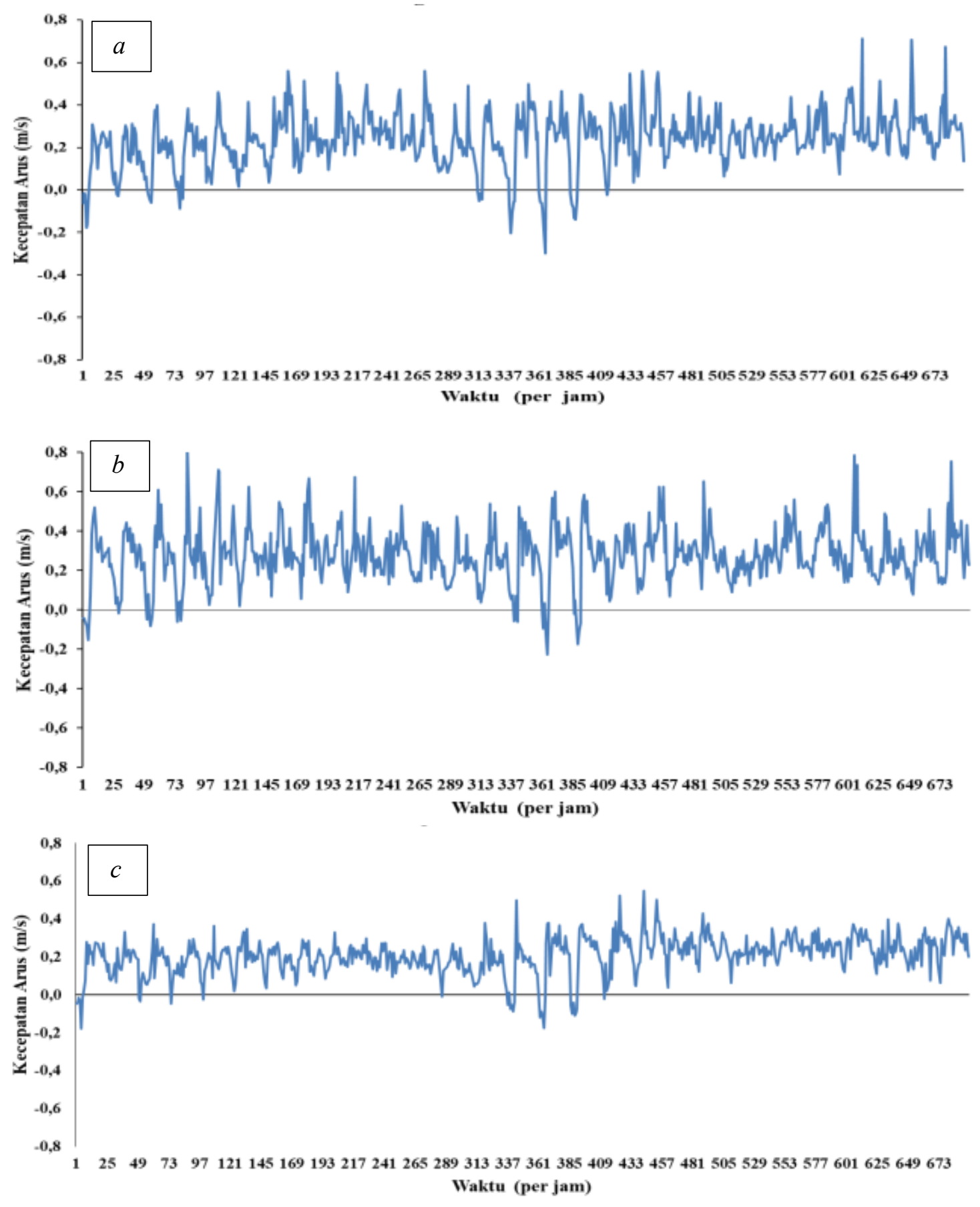

Gambar 4. Grafik pola pergerakan arus di Muara Mempawah: a) Stasiun 1; b) Stasiun 2;c) Stasiun 3

sebesar $41 \mathrm{~cm}, 40 \mathrm{~cm}$ dan $37 \mathrm{~cm}$. Hasil visualisasi data pengukuran pasang surut pada masing-masing stasiun pengamatan dapat dilihat pada Gambar 3 - 5.

\subsection{Arus}

Pergerakan arus pasang surut mempunyai tipe berubah arah atau bolak-balik di muara sungai akibat aliran yang dibatasi oleh geometri kanal (Utami, 2008; Surbakti, 2012). Hal tersebut menimbulkan arah aliran bergantian dalam arah yang hampir berlawanan. Pada saat air mulai pasang muka air di laut lebih tinggi daripada muka air sungai, akibatnya arus pasang surut akan bergerak memasuki sungai. Sebaliknya saat air 
Jurnal Laut Khatulistiwa, Vol. 4. No. 3 (October, 2021), Hal. 92-100.
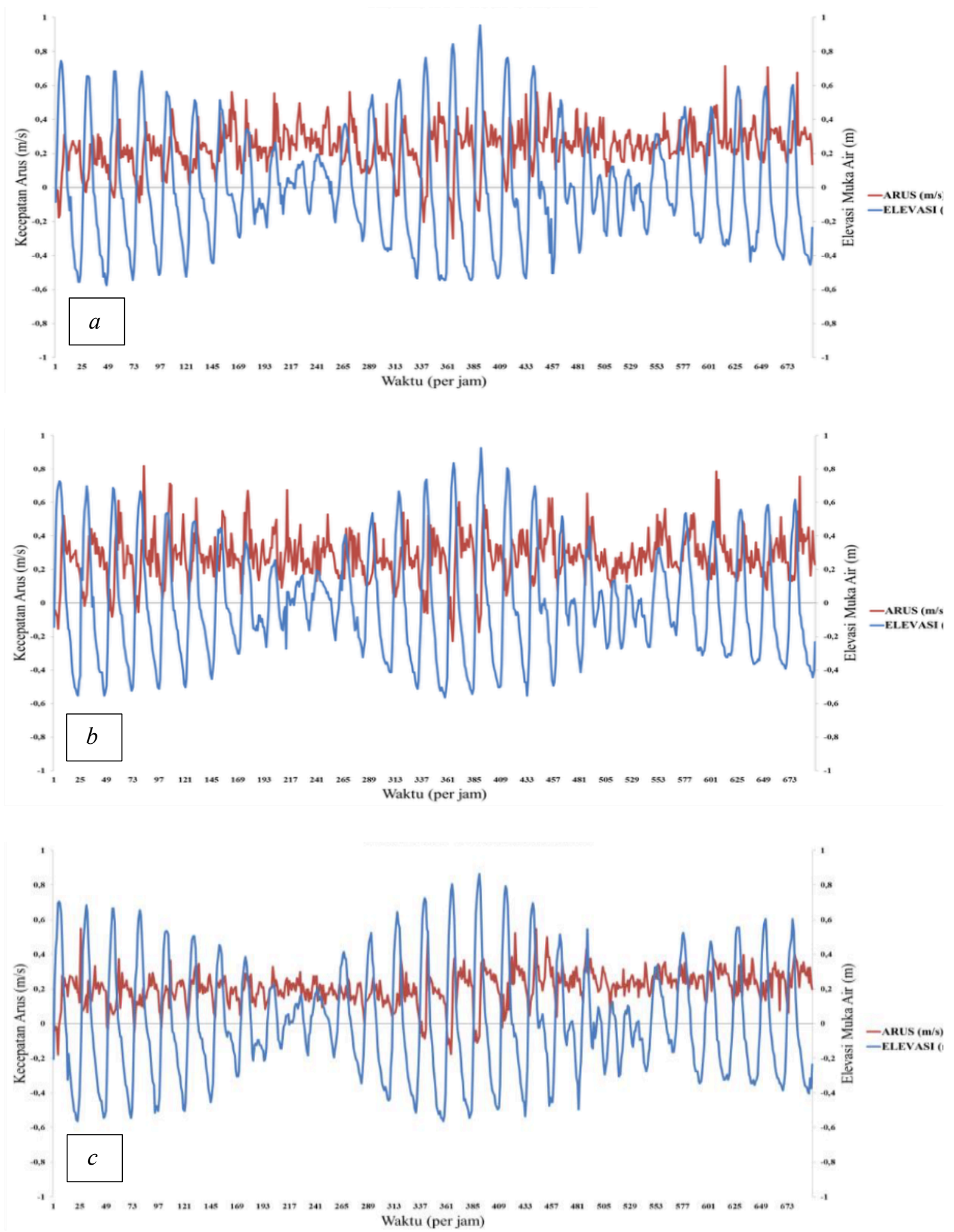

Gambar 5. Asimetri pasang surut di Muara Mempawah: a) Stasiun 1; b) Stasiun 2; c) Stasiun 3

mulai surut muka air di laut lebih rendah daripada muka air di sungai, akibatnya arus pasang surut akan bergerak keluar menuju laut (Kisnarti dan Prasita, 2019).
Hasil visualisasi data pengukuran arus pada masing-masing stasiun pengamatan disajikan pada Gambar 6 - 9. Nilai positif pada grafik menunjukan arah pergerakan arus yang 
Jurnal Laut Khatulistiwa, Vol. 4. No. 3 (October, 2021), Hal. 92-100.

keluar menuju laut, sedangkan nilai negatif menunjukan arah pergerakan arus yang masuk menuju sungai.

Berdasarkan hasil pengukuran data arus selama 29 hari secara kontinu diketahui bahwa pergerakan arus dominan keluar menuju laut. Pergerakan arus yang masuk menuju sungai hanya ditemukan pada saat periode pasang purnama, yaitu saat fase bulan baru dan bulan purnama. Kecepatan rata-rata arus yang didapatkan pada Stasiun 1 sebesar $0,24 \mathrm{~m} / \mathrm{s}$, pada Stasiun 2 sebesar $0,28 \mathrm{~m} / \mathrm{s}$, dan pada Stasiun 3 sebesar $0,21 \mathrm{~m} / \mathrm{s}$. Berdasarkan hasil penelitian diketahui bahwa rata-rata kecepatan arus pada Stasiun 3 lebih kecil dibandingkan kecepatan arus pada Stasiun 1 dan 2. Hal ini dapat dipengaruhi karena terdapat sebuah jembatan pada aliran sungai sehingga pondasi dari jembatan tersebut menyebabkan berkurangnya luas penampang sungai.

\subsection{Asimetris Pasut}

Asimetris pasut adalah salah satu fenomena yang dapat diamati di muara sungai. Menurut Dronkers, (1986) asimetri pasut merupakan perbedaan besarnya kecepatan arus dan perbedaan durasi waktu antara kondisi menuju pasang (flood) dan menuju surut $(e b b)$. Untuk dapat memahami bagaimana pengaruh tingkah laku pasang surut terhadap perubahan pola pergerakan arus, maka dilakukan visualisasi dengan cara menyandingkan data elevasi muka air (vertikal) dengan data arus (horizontal). Hasil visualisasi data elevasi muka air dan arus disajikan pada Gambar 9. Data elevasi muka air ditandai dengan garis warna biru pada grafik, sedangkan data arus ditandai dengan garis
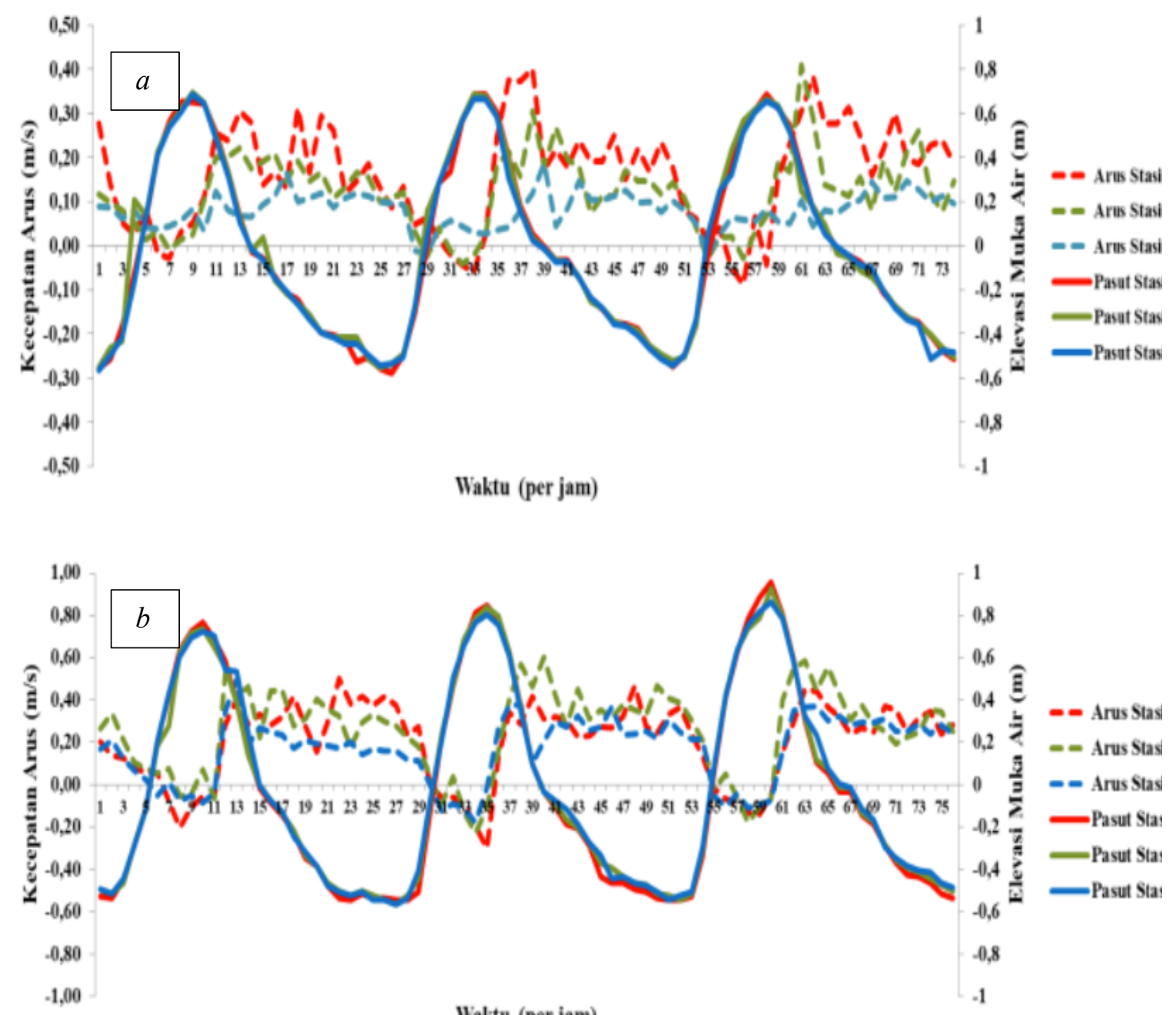

Waktu (per jam)

Gambar 6. Asimetri pasang surut di Muara Mempawah: $a$ ) bulan purnama; $b$ ) bulan baru 
warna merah. Berdasarkan hasil penelitian menunjukan ketidaksimetrisan antara kondisi menuju pasang dan menuju surut, dimana durasi waktu menuju pasang lebih cepat dibandingkan durasi waktu menuju surut. Kondisi ini dapat diamati dengan jelas pada saat periode pasang purnama, yaitu saat fase bulan baru dan bulan purnama.

Munculnya fenomena asimetri pasut terjadi akibat pengaruh berkurangnya kedalaman perairan sehingga menyebabkan kedalaman pada saat menuju pasang lebih besar dibandingkan kedalaman pada saat menuju surut. Hal tersebut menimbulkan interval waktu yang relatif lama antara air pasang dan air surut, serta interval waktu yang lebih pendek antara air surut dan air pasang berikutnya (The Open University, 1999).

Untuk dapat memahami dengan baik bagaimana pengaruh tingkah laku pasang surut terhadap perubahan pola pergerakan arus, maka dilakukan visualisasi data pada saat periode pasang purnama. Hasil visualisasi pada saat periode pasang purnama, yaitu saat fase bulan baru dan bulan purnama pada ketiga stasiun pengamatan dapat dilihat pada Gambar 10.

Pasang surut yang terjadi pada periode pasang purnama dapat menimbulkan arus yang bergerak masuk menuju sungai. Sedangkan pada saat periode pasang perbani tidak ditemukan arus yang bergerak masuk menuju sungai. Perbedaan nilai rentang pasut yang cukup signifikan antara periode pasang purnama dan periode pasang perbani dapat mempengaruhi besarnya kekuatan debit yang dihasilkan oleh pasang surut.

Berdasarkan hasil visualisasi data pada saat periode pasang purnama (bulan baru dan bulan purnama) akan dibagi menjadi 4 kondisi pasang surut. Kondisi pertama adalah menuju pasang, kondisi kedua adalah pasang tertinggi, kondisi ketiga adalah menuju surut dan kondisi keempat adalah surut terendah.

Pada kondisi pertama, yaitu menuju pasang terlihat bahwa kecepatan arus yang didapatkan terus berkurang hingga pada saat elevasi pasut mencapai MSL (mean sea level) ditemukan kecepatan arus yang sangat kecil, hingga alat ukur arus tidak mengalami perpindahan atau diam. Selanjutnya setelah elevasi pasut mencapai MSL terjadi perubahan arah arus yang bergerak masuk menuju sungai.
Kemudian pada kondisi kedua, yaitu pasang tertinggi terlihat bahwa secara umum arus masih bergerak masuk menuju sungai. Sedangkan pada kondisi ketiga, yaitu menuju surut terjadi perubahan arah arus yang bergerak keluar menuju laut disertai dengan peningkatan kecepatan arus yang signifikan. Selanjutnya pada kondisi keempat, yaitu surut terendah terlihat bahwa arus bergerak keluar menuju laut.

Beberapa hasil penelitian yang mengkaji tentang kondisi pasang surut dan arus di muara sungai, yaitu Surbakti, (2012); Simatupang et al, (2016) mendapatkan kecepatan arus maksimum terjadi saat air mulai pasang atau menuju pasang, sedangkan kecepatan arus minimum didapatkan pada saat air mulai surut atau menuju surut dengan tipe pasut adalah harian tunggal. Berdasarkan hal tersebut diketahui bahwa kondisi arus yang dipengaruhi oleh pasang surut tidak sama atau berbeda pada setiap tempat.

\section{Kesimpulan}

Berdasarkan hasil penelitian dapat disimpulkan bahwa pada saat pasang purnama, ditemukan arus yang bergerak memasuki sungai saat kondisi menuju pasang dengan kecepatan arus yang ralatif kecil. Hingga pada saat elevasi pasut mencapai MSL (mean sea level) kecepatan arus yang ditemukan sangat kecil, yaitu $0 \mathrm{~m} / \mathrm{s}$. Sebaliknya saat menuju surut arus bergerak keluar menuju laut dengan kecepatan arus yang ditemukan mengalami peningkatan secara signifikan.

\section{Daftar Pustaka}

Badan Pusat Statistik Kabupaten Mempawah. 2018. Kecamatan Mempawah Hilir Dalam Angka, 12-15p.

Dronkers, J. 1986. Tidal Asymmetry and Estuarine Morphology, Netherlands Journal of Sea Research, 117-131p.

Fadilah, Suripin, D.P. Sasongko,. 2014. Menentukan Tipe Pasang Surut dan Muka Air Rencana Perairan Laut Kabupaten Bengkulu Tengah Menggunakan Metode Admiralty. Maspari Journal. 6(1):1-12.

Hidayah, Z., A.D. Mahatmawati. 2010. Perbandingan Fluktuasi Muka Air Laut Rerata (MLR) Di Perairan Pantai Utara 
Jurnal Laut Khatulistiwa, Vol. 4. No. 3 (October, 2021), Hal. 92-100.

Jawa Timur Dengan Perairan Pantai Selatan Jawa Timur. Jurnal Kelautan. 3.

Kisnarti, E.A., Prasita, V.D., 2019, Pemodelan Hidrodinamika Muara Sungai Studi Kasus : Muara Sungai Porong Sidiorjo, Hang Tuah Press, Surabaya.

Leonardi, N., Kolker, A.S., Fagherazzi, S., 2015, Interplay Between River Discharge and Tides in a Delta Distributary, Advances in Water Resources, 80:69-78.

Niroomandi, A., Ma, G., Su, S.F., Gu, F., Qi, D., 2017, Sediment Flux And SedimentInduced Stratification In The Changjiang Estuary. Journal Mar Sci Technol. 23:349463.

Nugroho, A., Ismunarti, D.H., Rochaddi, B., 2015, Studi Karakteristik Dan Co-Range Pasang Surut Di Teluk Lembar Lombok Nusa Tenggara Barat, Jurnal Oseanografi, 4(1):93-99.

Pickard, G.L., Descriptive Physical Oceanography Ed ke-2, Pergamon Press, Inggris.

Sudarto, 1993, Pembuatan Alat Ukur Arus Secara Sederhana, Jurnal Oseana, 28(1):35-44.

Surbakti, H., 2012, Karakteristik Pasang Surut Dan Pola Arus Di Muara Sungai Musi Sumatera Selatan, Jurnal Penelitian Sains, 15(1):08-35.

Simatupang, C.M., Surbakti, H., Agussalim, A., 2016, Analisis Data Arus Di Perairan Muara Sungai Banyuasin Provinsi Sumatera Selatan, Maspari Journal, 8(1):15-24.

Triadmodjo, 1999, Teknik Pantai, Beta Offset, Yogyakarta

The Open University, 1999, Waves Tides and Shallow Water Processes Ed ke-2, Butterworth-Heinemann, Oxford, 227hal.

Utami, D.A., 2008, Studi Arus Pasang SurutDan Arus Tetap Di Selat Lombok, Institut Teknologi Bandung , Program Studi Osenografi Fakultas Ilmu Dan Teknologi Kebumian, Bandung (Skripsi).

Widyastuti, M.S., 2014, Pemodelan Fluks Garam di Estuari Kapuas, Institut Teknologi Bandung, Program Studi Sains Kebumian, Bandung, (Tesis). 